\title{
EVALUATION OF HOTEL COMPANIES OWNING FIVE-STAR HOTELS IN PRIMORSKO-GORANSKA COUNTY (CROATIA) USING THE MULTI-CRITERIA APPROACH
}

\author{
JELENA JARDAS ANTONIĆIA, IVANA MATKOVIĆ², KRISTINA KAŠTELANIB \\ ${ }^{1}$ University of Rijeka, Faculty of Economics, Department of Quantitative Economics ${ }^{a}$, \\ Department of Foreign Languages ${ }^{b}$, Rijeka, Croatia \\ 2 Former student at Faculty of Economics and Business, accountant
}

\author{
Mailing address: Jelena Jardas Antonić, University of Rijeka, Faculty of Economics, Department of \\ Quantitative Economics, 4 Ivana Filipovića Street, 51000 Rijeka, \\ tel.: +385 51 355140, e-mail: jelena.jardas.antonic@efri.hr
}

\begin{abstract}
Introduction. High-category hotels are considered to be one of the most important elements of every tourist destination's supply. Recently, the lack of highly rated hotels in the Republic of Croatia has often been criticized by the public because they are believed to be a prerequisite in the creation of a competitive tourist offer. Material and methods. The authors have performed a multi-criteria decision analysis of eight companies owning five-star hotels in Primorsko-Goranska County using the Analytic Hierarchy Process (AHP) method. Their business performance was evaluated based on both financial and market criteria. The financial criteria encompassed indicators of liquidity, indebtedness, activity and profitability. Data regarding the market indicators were collected using a questionnaire. Results. The importance of market criteria in the tourism industry is visible in tourist demand, which is founded on the perception of potential hotel guests, their recognition of the brand and thus the market potential of the hotels themselves. Therefore, both the financial and market aspect have been included in the Analytic Hierarchy Process analysis and synthesized to estimate the overall priority based on which the hotels were ranked. According to all criteria and sub-criteria, the best ranked hotel company is Eles Turizam j.d.o.o with its five-star hotel Mozart (0.2540), followed by Milenij hotels d.o.o. with its Milenij and Milenij Sveti Jakov. The third place has been assigned to Liburnija Rivijera Hoteli d.o.o. and its Ambasador. Conclusions. All but one of the analyzed five-star hotels are under the ownership of the biggest hotel companies in PGŽ with a long presence in the tourism industry. Therefore, it was expected that, due to their market recognizability and, consequently, their good financial performance, they would rank first. However, the research has shown that market potential does not necessarily imply best practices. Eles Turizam and its hotel Mozart were ranked the highest according to financial and overall priority scores. It may thus be concluded that even a small family hotel company with reduced marketing costs, especially one with an elite tourist offer, can compete with big hotel companies if it continuously assures the quality of its services.
\end{abstract}

Key words: hotel industry, Analytic Hierarchy Process, criteria, performance, benchmark

\section{Introduction}

The hotel industry in the Republic of Croatia represents a very important drive in tourist activities and tourism itself. The challenge faced by the Croatian tourism industry lies in the insufficient number of high-category hotel accommodation. Hotel services should be adapted to the needs of new tourists, and guests should be provided with a personalized experience [1]. There are numerous destinations offering similar attractions, services and experiences; therefore, hotel managers need to put an additional effort into differentiating their offer from that of their competitors. This means managers are expected to successfully cope with today's global, competitive and dynamic environment through effective planning and enhancement of quality in order to satisfy the high standards required by today's tourists.

In previous research which analyzed five-star hotels using multi-criteria analysis, the hotels were benchmarked based on the corporate social responsibility (CSR) concept [2]. Kheiri [3] did a follow-up on this research in 2015, where he used the concept of corporate social responsibility as a means of analyzing and selecting the best practices in five-star hotel brands in Te- hran. Furthermore, in their work published in 2014, Anna M. Gil-Lafuente, José M. Merigó \& Emilio Vizuete [4] used fuzzy analytic hierarchy process (AHP) and TOPSIS multi-criteria analysis to determine the order of criteria according to which the consumer perceives a hotel as a high-category hotel. Other papers, such as the one by Hokey Min et al. [5] from 2002, focused on multi-criteria analysis of hotel service quality. Croatian authors have examined high-category hotels statistically based on 7 business quality dimensions [6] and based on multi-criteria analysis of information system significance in hospitality performance [7].

According to the 2017 statistics published by the Ministry of Tourism of the Republic of Croatia, hotel accommodation was ranked as the top two choices by both foreign and domestic tourists. Moreover, based on these statistics, Primorsko-Goranska County recorded the largest number of incoming tourists $(16 \%)$. These figures motivated us to research high-category, that is five-star hotels in Primorsko-Goranska County. We have decided to evaluate the hotels using multi-criteria decision making and rank them according to financial and market criteria. According to our knowledge, previous studies on hotels in the Republic of Croatia have not used multi-criteria analysis, 
especially when it comes to high-category hotels. Thus, the aim of this paper is to compare and benchmark all five-star hotels in Primorsko-Goranska County and to explore the possibilities of improving the existing offer.

\section{Material and methods}

The Analytical Hierarchy Process (AHP) is a multi-attribute decision method that enables combining quantitative and qualitative criteria. According to Mardani et al., AHP is the method which is used the most frequently in multiple-criteria decision making [8]. AHP is aimed at integrating different measures into a single overall priority vector as the final score for ranking decision alternatives. In order to construct an overall priority vector, it is necessary to compare each pair of criteria among themselves and then to compare alternatives in relation to each criterion. Once this has been done, a priority matrix can be constructed and normalized to calculate the overall priority vector.

The AHP method has the advantage of highlighting the main attributes, strengths and weaknesses of every alternative. This mathematical method is the key in selecting the main criteria and ranks them according to importance. The AHP method forms priorities by comparing each alternative/criterion with all the other alternatives/criteria, that is making relative comparisons between them using Saaty's scale.

The following section provides an explanation of the AHP mathematical model, particularly in the calculation of weights, starting from the paired comparison technique and ending with consistency verification. By determining the weights, each alternative is assigned a numerical value indicating the level of importance within each criterion. The AHP provides an answer to the question whether one criterion is preferable to another and if so, to what extent. To avoid subjectivity, the qualitative comparison has to be performed by an expert (or a group of experts) familiar with the subject or, alternatively, a survey can be conducted. In the current study, we opted for the latter; we asked the respondents to express their personal opinions and classified their responses according to a scale developed by Thomas L. Saaty [9]. The method used can be explained in three basic steps derived from Satty's seven pillars of AHP [10].

First, a pair-wise comparison decision matrix (A) is created according to the following formula:

$$
A=\left[a_{i m}\right]\left[\begin{array}{ccc}
1 & \ldots & a_{1 n} \\
\ldots & \ldots & \ldots \\
\frac{1}{a_{1 n}} & \ldots & 1
\end{array}\right] \text {, for } i, m=1,2,3 \ldots, n
$$

where $A_{1}, A_{2}, \ldots$, An denote the set of elements, while $a_{\text {im }}$ represents a quantified judgment on a pair of elements, $A i$ and $A m$. In order to be able to make comparisons among criteria and among alternatives with respect to the criterion or property based on which they are compared, a numerical scale is needed. With this in mind, Saaty developed a measurement scale for pair-wise comparison, which was used in the current study (Table 1). Verbal judgments are expressed by degree of preference, and this degree is related to a particular level of intensity of importance.

Secondly, the decision matrix is normalized by summing up all sets of individual column values. Each of these values is divided by its respective column-total value. Finally, the row average and the weights assigned to the decision-maker's objectives are calculated. A set of $n$ numerical weights $w 1, w 2, \ldots, w i$ are obtained.

Thirdly, the eigenvalue is calculated and a consistency analysis is performed:
Table 1. Saaty's scale

\begin{tabular}{|c|c|c|}
\hline $\begin{array}{l}\text { Intensity of } \\
\text { importance }\end{array}$ & Definition & Explanation \\
\hline 1 & Equal importance & $\begin{array}{l}\text { Two activities contribute } \\
\text { equally to the objective. }\end{array}$ \\
\hline 2 & Weak or slight & \\
\hline 3 & Moderate importance & $\begin{array}{c}\text { Experience and judgement } \\
\text { slightly favour one activity } \\
\text { over another. }\end{array}$ \\
\hline 4 & Moderate plus & \\
\hline 5 & Strong importance & $\begin{array}{l}\text { Experience and judgement } \\
\text { strongly favour one activity } \\
\text { over another. }\end{array}$ \\
\hline 6 & Strong plus & \\
\hline 7 & $\begin{array}{l}\text { Very strong or demonstrated } \\
\text { importance }\end{array}$ & $\begin{array}{l}\text { An activity is favoured very } \\
\text { strongly over another. }\end{array}$ \\
\hline 8 & Very, very strong & \\
\hline 9 & Extreme importance & $\begin{array}{l}\text { The evidence favouring one } \\
\text { activity over another is of } \\
\text { the highest possible order } \\
\text { of affirmation. }\end{array}$ \\
\hline $\begin{array}{l}\text { Reciprocals } \\
\text { of above }\end{array}$ & $\begin{array}{l}\text { If activity } i \text { has one of the above } \\
\text { non-zero numbers assigned to } \\
\text { it when compared with activity } \\
j \text {, then activity } j \text { has reciprocal } \\
\text { value when compared with } i\end{array}$ & \\
\hline
\end{tabular}

Source: Saaty [9]

$$
A w_{i}=\lambda_{\text {max }} w_{i}, i=1,2,3, \ldots n
$$

where $\lambda_{\max }$ represents the characteristic value. The consistency ratio $(\mathrm{CR})$ is calculated as the ratio between the consistency index $(\mathrm{CI})$ and the random index $(\mathrm{RI})$, that is

$$
\mathrm{CR}=\frac{\mathrm{CI}}{\mathrm{RI}}
$$

The random index represents the consistency index obtained from multiplicity randomly generated pair-wise comparison matrices of range $n$. The value of the random index depends on the matrix range. Random index values are given in Table 2.

Table 2. Values of the RI index depending on $n$

\begin{tabular}{|c|c|c|c|c|c|c|c|c|c|c|c|c|c|c|c|}
\hline $\mathrm{N}$ & 1 & 2 & 3 & 4 & 5 & 6 & 7 & 8 & 9 & 10 & 11 & 12 & 13 & 14 & 15 \\
\hline $\mathrm{RI}$ & 0.00 & 0.00 & 0.52 & 0.89 & 1.11 & 1.25 & 1.35 & 1.40 & 1.45 & 1.49 & 1.51 & 1.54 & 1.56 & 1.57 & 1.58 \\
\hline
\end{tabular}

Source: Saaty [9].

For the analysis to be consistent, the calculated CR (consistency ratio) should be below 0.1 .

For the purpose of this research, ten five-star hotels in Primorsko-Goranska County run by eight hotel companies have been taken into consideration. The respective hotels and companies are as follows: Alhambra and Bellevue (Jadranka Hoteli d.o.o.), Amabilis (MGL International d.o.o.), Ambasador (Liburnia Riviera Hoteli d.d.), Bevanda (Bevanda Hoteli d.o.o.), Milenij and Milenij Sveti Jakov (Milenij Hoteli d.o.o.), Mozart (Eles Turizam j.d.o.o.), Navis (Villa Kapetanović d.o.o.) and The View (Valtur International d.o.o).

All hotel companies have been evaluated according to two main criteria and eight sub-criteria. The hotel company Bev- 
anda was excluded from the overall analysis because of the unavailability of the financial data for 2016.

The success of a hotel does not only depend on its financial performance but also on its market recognition. Therefore, for the purposes of this paper, both of these criteria have been included in the performance evaluation. All criteria and subcriteria included in the analysis of company performance are shown in Figure 1.

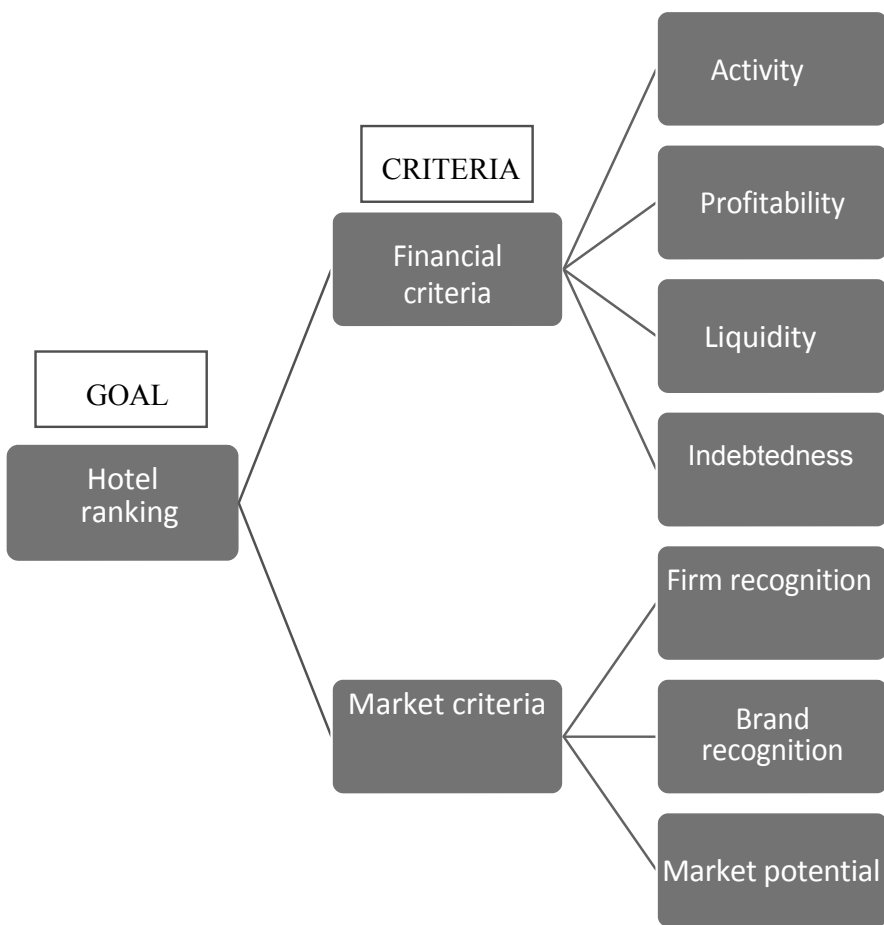

Source: Authors' own research.

Figure 1. Hierarchical representation of performance evaluation

Financial criteria were obtained based on financial reports - the profit and loss accounts, that is the calculation of the financial indicators of liquidity, indebtedness (measured based on leverage ratio), activity (measured using net asset turnover) and profitability (measured using return on equity) for 2016. The market rating of the company and respective hotels was determined by means of a questionnaire in the Google Docs application, which was distributed to employees of tourism agencies in Primorsko-Goranska County. The respondents were asked to assess the recognizability and market position of each company and the respective hotel(s) according to their knowledge and experience.

The financial indicators for the eight hotel companies owning five-star hotels in Primorsko-Goranska County are shown in Table 3.

As can be seen in Table 3, the liquidity ratio values show that MGL International d.o.o. and Eles Turizam j.d.o.o have sufficient funds for financing short-term liabilities whereas the liquidity ratios of all of the other hotel companies are below the recommended values. The most indebted companies are Villa Kapetanović d.o.o., Milenij Hoteli d.o.o., and MGL International d.o.o. The reason for this may lie in these companies' investment activities. Both the values of net asset turnover and ROE are below the recommended values for all companies except for
Table 3. Financial indicators for five-star hotels and respective hotel companies in Primorsko-Goranska County for 2016

\begin{tabular}{|l|c|c|c|c|}
\hline \multicolumn{1}{|c|}{ Hotel company } & $\begin{array}{c}\text { Liquidity } \\
\text { ratio }\end{array}$ & $\begin{array}{c}\text { Indebtedness } \\
\text { (measured } \\
\text { based on } \\
\text { leverage } \\
\text { ratio) in } \%\end{array}$ & $\begin{array}{c}\text { Activity } \\
\text { (measured } \\
\text { using net } \\
\text { asset } \\
\text { turnover) }\end{array}$ & $\begin{array}{c}\text { Profitability } \\
\text { (measured } \\
\text { using return } \\
\text { on equity } \\
\text { in \%) }\end{array}$ \\
\hline Jadranka Hoteli d.o.0. & 0.11 & 0.45 & 0.19 & 0.07 \\
\hline MGL International d.o.0. & 3.17 & 0.74 & 0.19 & 0.09 \\
\hline Liburnia Rivijera Hoteli d.d. & 0.04 & 0.21 & 0.29 & 0.02 \\
\hline $\begin{array}{l}\text { Bevanda Hoteli } \\
\text { d.o.0. }\end{array}$ & $\begin{array}{c}\text { The company turned in a statement of inactivity for } 2016 \\
\text { (not included in the calculations of financial indicators). }\end{array}$ \\
\hline Milenij Hoteli d.0.0. & 0.40 & 0.80 & 0.53 & 0.01 \\
\hline Eles Turizam j.d.o.0. & 3.53 & 0.35 & 2.12 & 0.34 \\
\hline Vila Kapetanovic d.0.0. & 0.27 & 0.80 & 0.23 & 0.11 \\
\hline Valtur International d.0.0. & 1.32 & 0.25 & 0.79 & 0.08 \\
\hline
\end{tabular}

Source: Authors' own analysis of the financial reports available at http://rgfi.fina.hr/ JavnaObjava-web/pSubjektTrazi.do [11].

Eles Turizam j.d.o.o., which has a net asset turnover of 2.12 and a ROE of 0.34 .

To avoid subjectivity in market rating, the authors conducted a questionnaire survey on the market recognizability and market position of each hotel company. The questionnaires were completed by 61 tourism agency employees. The obtained data made it possible to calculate weights according to which the three sub-criteria were quantified using the AHP method. Moreover, as the responses to the questionnaire greatly depended on the respondents' experience and general knowledge related to the tourism industry, the authors grouped the respondents according to age, as shown in Figure 2.

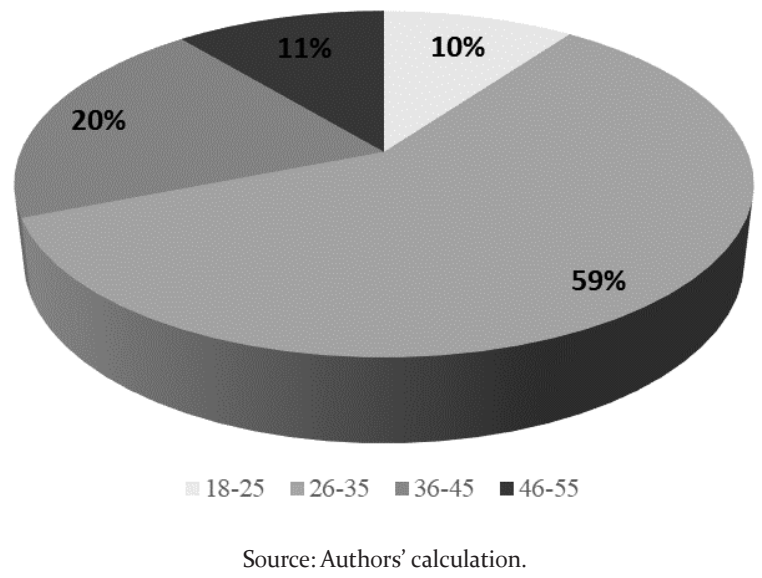

Figure 2. Distribution of respondents according to age

Most of the respondents (59\%) were aged between 26 and 35 years, $20 \%$ of them were aged between 36 and 45 years and $11 \%$ of them were $46-55$ years old. Only $10 \%$ of the respondents belonged to the age group between 18 and 25 years. None of the respondents were above 56 years of age. As far as gender is concerned, there were $40.98 \%$ of male and $59.02 \%$ of female respondents. 
The first sub-criterion refers to a given hotel company's recognizability and presence on the market. According to the first criterion, Liburnia Riviera Hoteli d.d. is the most recognizable company, followed by Milenij Hoteli d.o.o.

The second sub-criterion refers to the recognizability of the individual five-star hotels. Out of the ten analyzed hotels operating in Primorsko-Goranska County, eight were recognized. The most recognizable brand (hotel) was Ambasador (Liburnia Rivijera Hoteli d.d.) followed by Milenij (Milenij Hoteli d.o.o)

The third sub-criterion addressed the hotels' perspectives and potential with respect to developing new services resulting in increased market potential, that is better recognizability of a given hotel. All of the hotels were graded as having market potential, the two leading hotels being Ambsador and Milenij.

\section{Results}

The ranking of eight hotels and respective hotel companies according to 7 sub-criteria would be a rather demanding process if done without multi-criteria analysis. Therefore, the authors opted for the analytic hierarchy process (AHP), which made it possible to rank the companies and their hotels according to both market and financial criteria. The first two groups of criteria, that is market and financial criteria, were compared based on the criteria defined by the Croatian Chamber of Commerce (HGK) [12] to see which of these were more relevant. According to HGK criteria and Saaty's scale, the financial criteria group is three times more important than the market criteria group. In other words, in business practice, the success of a company's operations is mostly measured based on financial criteria. The following tables show the ratios between criteria and sub-criteria.

Table 4. Criteria evaluation

\begin{tabular}{|c|c|c|}
\hline Criteria preferences & Financial criteria & Market criteria \\
\hline Financial criteria & 1 & 3 \\
\hline Market criteria & $1 / 3$ & 1 \\
\hline
\end{tabular}

Source: Authors' calculation.

After assigning the weights to the two main groups of criteria, we were able to assign weights to the financial sub-criteria. As the consistency ratio for all sub-criteria is below 0.1 , it may be said that the weight assigning is consistent (see Tab. 5).

Table 5. Financial sub-criteria evaluation

\begin{tabular}{|l|c|c|c|c|}
\hline $\begin{array}{c}\text { Sub-criteria } \\
\text { preferences }\end{array}$ & Activity & Profitability & Liquidity & Indebtedness \\
\hline Activity & 1 & $1 / 6$ & $1 / 6$ & 1 \\
\hline Profitability & 6 & 1 & 3 & 5 \\
\hline Liquidity & 6 & $1 / 3$ & 1 & 4 \\
\hline Indebtedness & 1 & $1 / 5$ & $1 / 4$ & 1 \\
\hline
\end{tabular}

Note: $\mathrm{CR}=0.0517$;

Source: Authors' calculation.

In the following section, we present the steps taken in the ranking of hotel companies in accordance with market criteria. First, the market sub-criteria were pair-wised (Tab. 6). Later on, weights were assigned to each alternative (hotel company/hotel) for each individual market sub-criterion through pair-wise comparison in accordance with data obtained via the questionnaire (Tab. 7).
Table 6. Market sub-criteria evaluation

\begin{tabular}{|l|c|c|c|}
\hline \multicolumn{1}{|c|}{$\begin{array}{c}\text { Sub-criteria } \\
\text { preferences }\end{array}$} & $\begin{array}{c}\text { Company } \\
\text { recognition }\end{array}$ & $\begin{array}{c}\text { Hotel } \\
\text { recognition }\end{array}$ & $\begin{array}{c}\text { Market } \\
\text { potential }\end{array}$ \\
\hline Company recognition & 1 & $1 / 3$ & 1 \\
\hline Hotel recognition & 3 & 1 & 3 \\
\hline Market potential & 1 & $1 / 3$ & 1 \\
\hline
\end{tabular}

Note: $\mathrm{CR}=0.0000$;

Source: Authors' calculation.

Table 7. Alternative ranking with respect to market sub-criteria

\begin{tabular}{|l|c|c|c|c|}
\hline \multicolumn{1}{|c|}{ Alternatives } & $\begin{array}{c}\text { Company } \\
\text { recognition }\end{array}$ & $\begin{array}{c}\text { Hotel } \\
\text { recognition }\end{array}$ & $\begin{array}{c}\text { Market } \\
\text { potential }\end{array}$ & $\begin{array}{c}\text { Overall } \\
\text { market } \\
\text { priority }\end{array}$ \\
\hline Jadranka Hoteli d.o.o. & 0.0158 & 0.0300 & 0.0257 & 0.0715 \\
\hline MGL International d.o.o. & 0.0072 & 0.0300 & 0.0063 & 0.0434 \\
\hline Liburnia Rivijera Hoteli d.d. & 0.0948 & 0.2100 & 0.0623 & 0.3671 \\
\hline Bevanda Hoteli d.o.o. & 0.0156 & 0.0300 & 0.0068 & 0.0524 \\
\hline Milenij Hoteli d.o.o. & 0.0447 & 0.2100 & 0.0692 & 0.3240 \\
\hline Eles Turizam j.d.o.o. & 0.0069 & 0.0300 & 0.0085 & 0.0454 \\
\hline Vila Kapetanović d.o.o. & 0.0080 & 0.0300 & 0.0112 & 0.0492 \\
\hline Valtur International d.o.o. & 0.0069 & 0.0300 & 0.0100 & 0.0469 \\
\hline
\end{tabular}

Source: Authors' calculation.

Table 7 shows that according to market criteria, Liburnija Rivijera Hoteli d.o.o is ranked highest, followed by Milenij Hoteli d.o.o. (88.3\% of the value of the company ranked best). Jadranka Hoteli d.o.o. is ranked third (having $18.5 \%$ of the value for the company ranked first), Bevanda Hoteli d.o.o. is ranked fourth (14.3\%) and Vila Kapetanović d.o.o. is ranked fifth (13.4\%). Valtur International d.o.o., Eles Turizam j.d.o.o and MGL International d.o.o. are sixth, seventh and eighth, with values amounting to $12.8 \%, 12.4 \%$ and $11.8 \%$ of that for the company ranked first, respectively.

After assigning the weights, we normalized the priority vectors in order to obtain the overall priority vector, that is to rank all alternatives according to both groups of criteria (Tab. 8).

Table 8. Overall priority results and ranking alternatives

\begin{tabular}{|l|c|c|c|}
\hline \multicolumn{1}{|c|}{ Alternatives } & $\begin{array}{c}\text { Financial } \\
\text { criteria }\end{array}$ & $\begin{array}{c}\text { Market } \\
\text { criteria }\end{array}$ & $\begin{array}{c}\text { Overall } \\
\text { priority }\end{array}$ \\
\hline Jadranka Hoteli d.o.o. & 0.0440 & 0.0229 & 0.0668 \\
\hline MGL International d.o.o. & 0.0941 & 0.0112 & 0.1052 \\
\hline Liburnia Rivijera Hoteli d.d. & 0.0500 & 0.0895 & 0.1394 \\
\hline Milenij Hoteli d.o.o. & 0.0970 & 0.0895 & 0.1864 \\
\hline Eles Turizam j.d.o.o. & 0.2414 & 0.0126 & 0.2540 \\
\hline Vila Kapetanović d.o.o. & 0.1046 & 0.0112 & 0.1158 \\
\hline Valtur International d.o.o. & 0.1190 & 0.0133 & 0.1322 \\
\hline
\end{tabular}

Source: Authors' calculation.

By synthesizing financial and market priorities, the overall priority, that is the overall ranking, is obtained. According to all criteria and sub-criteria, the best ranked hotel company is Eles Turizam j.d.o.o, with its five-star hotel Mozart (0.2540), followed by Milenij hotels d.o.o., with its Milenij and Milenij Sveti Jakov. The third place has been assigned to Liburnija Rivijera Hoteli d.o.o. and its Ambasador. 


\section{Conclusions}

The tourism industry in Croatia is a very important generator of the country's GDP. Since it is generally believed that high-quality hotels in the Republic of Croatia represent a key driver of the tourist offer, it would be desirable to increase their number and consequently the number of hotels that could serve as examples of good practice based on financial results and market recognition. The same may be said for Primorsko-Goranska County (PGŽ). In order to provide an example of good practice operating in PGŽ, we ranked the existing seven active hotel companies owning five-star hotels in PGŽ using AHP multi-criteria decision-making analysis. The hotels and respective hotel companies were ranked according to financial and market criteria. Two hotels were eliminated from the analysis due to the lack of data meeting selected financial criteria and pertinent sub-criteria. The assumption behind the ranking, in accordance with the Croatian Chamber of Commerce, was that financial criteria are three times more important than market criteria. Given that financial ratings and market ratings were found to be different, these two rankings were synthesized. By synthesizing priorities, we obtained the overall priority or ranking. The best ranked hotel company in 2016 was Eles Turizam j.d.o.o with its five-star hotel Mozart (0.2540), followed by Milenij hotels d.o.o. with its Milenij and Milenij Sveti Jakov (0.1864) hotels and Liburnija Riviera hotels d.d. with its Ambasador hotel (0.1394). The inconsistencies in the pair-wise comparison were very small because the consistency ratio was 0.0003 , indicating that the consistency level was not disturbed and that the results of the analysis were valid. The results obtained can serve as a good basis for benchmarking. This would enable hotel managers to improve the relative financial and market performance of their hotels, based on a comparison with best ranked hotels in their category.

Moreover, it should be pointed out that all five-star hotels in PGŽ except Mozart are under the ownership of the biggest hotel companies in PGŽ, which have long been present in the tourism industry. This is a possible reason behind their market recognizability, that is their market potential, and, consequently, their good financial performance. However, our research has shown that market potential does not necessarily imply best practices. Eles Turizam and its hotel Mozart were ranked the highest according to financial and overall priority scores. Therefore, it may be concluded that even a small family hotel company with reduced marketing costs can compete with big hotel companies, especially if it provides an elite tourist offer, continuously assuring the quality of its services. Therefore, future research could be aimed at determining which quality segments (criteria) and to what extent impact a hotel company's profitability.

\section{Acknowledgements}

This paper has been financially supported by the University of Rijeka, under Project ZP UNIRI 2/19.

\section{Literature}

1. Vitasovic A. (2014). Competitive positioning of tourist offer of the Republic of Croatia. In J. Grzinic, V. Bevanda (eds), Contemporary trends in tourism (pp. 116-153), Pula: University of Juraj Dobrila in Pula, Faculty of Economics and2. Kheiri J., Yazdanpanah E., Soleymaninejad M., Sajjadi F., Taslimi M. (2015). Ranking five star hotels in Tehran using CSR. International Journal of Information Science 5(2), 3041.

3. Kheiri J. (2015). Assessing and ranking the corporate social responsibility behavior of five star hotels in Tehran using the AHP and FTOPSIS methods. Journal of Information Technology \& Software Engineering 6(2), 165. DOI: 10.4172/2165-7866.1000165.

4. Gil-Lafuente A.M., Merigó J.M., Vizuete E. (2014). Analysis of luxury resort hotels by using the Fuzzy Analytic Hierarchy Process and the Fuzzy Delphi Method. Economic Research 27(1), 244-266. DOI: 10.1080/1331677X.2014.952106.

5. Min H., Min H., Chung K. (2002). Dynamic benchmarking of hotel service quality. Journal of Services Marketing 16(4), 302-321. DOI: 10.1108/08876040210433211.

6. Žilić I. (2012) Business excellence in high-category hotels in Croatia. Ekonomska Misao i Praksa 21(1), 123-142. [in Craotian]

7. Garbin Praničević D., Srića V. (2013). AHP support to estimation of the Information System (IS) significance to the business performance, particularly the hospitality performance. Croatian Operational Research Review 4, 211-222.

8. Mardani A., Jusoh A., Nor K., Khalifah Z., Zakwan N., Valipour A. (2015). Multiple criteria decision-making techniques and their applications - A review of the literature from 2000 to 2014. Economic Research 28(1), 516-571. DOI: 10.1080/1331677X.2015.1075139.

9. Saaty T.L. (2008). Decision making with the analytic hierarchy process. International Journal of Services Sciences 1(1), 83-98.

10. Saaty T.L., Vargas L.G. (2012). Models, methods, concepts \& applications of the analytic hierarchy process. Boston, MA: Springer.

11. Annual Financial Reports Registry (2019), Retreived March 5, 2019, from http://rgfi.fina.hr/JavnaObjava-web/pSubjektTrazi.do. [in Croatian]

12. Croatian Chamber of Commerce (2016). Hotel assessment criteria applied by the Croatian Chamber of Commerce "Tourism industry - Quality for Croatia 2016”. Zagreb: Eurochambers. Retrieved March 5, 2019, from https://www.hgk. $\mathrm{hr}$ /documents/kriteriji-ocjenjivanja578ccaa5e9e36.pdf. [in Croatian] Tourism.

Submitted: June 27, 2019.

Accepted: October 24, 2019. 